Research article

\title{
The Role of Parenting to Increase Gross and Fine Motor Skills Development in Children Aged 5-6 Years
}

\author{
I Gusti Ayu Putu Satya Laksmi ${ }^{1}$, Ni Made Nopita Wati ${ }^{2}$, R. Tri Rahyuning Lestari ${ }^{3}$ \\ 1,2,3 Departemen Keperawatan, Program Studi Keperawatan Program Sarjana, STIKes Wira Medika Bali
}

\begin{tabular}{|c|c|}
\hline Article Info & Abstract \\
\hline $\begin{array}{l}\text { Article History: } \\
\text { Accepted May 29th, } 2020 \\
\text { Keywords: } \\
\text { Parenting style; Motor } \\
\text { Development; Children 5-6 } \\
\text { years old }\end{array}$ & $\begin{array}{l}\text { Children's development includes several aspects including aspects of motor } \\
\text { development, cognitive, social-emotional, language, moral, religion. One of } \\
\text { the factors that influence motor development is parenting. The purpose of } \\
\text { this study was to determine the relationship between parenting parents } \\
\text { with gross motor and fine motor development in children aged } 5-6 \text { years. } \\
\text { This study used a quantitative non-experimental correlational type research } \\
\text { design with a cross-sectional approach. The sample consisted of } 75 \\
\text { respondents using a non-probability sampling technique with purposive } \\
\text { sampling. the majority of parents applying democratic parenting, as many as } \\
69 \text { people ( } 92 \%) \text {, most children aged } 5-6 \text { years have appropriate motor } \\
\text { development, as many as } 65 \text { people ( } 86.6 \%) \text {, most children aged } 5-6 \text { years } \\
\text { have appropriate fine motor development, as many as } 72 \text { people ( } 96 \% \text { ), } \\
\text { there is a strong relationship between parenting parents with gross motor } \\
\text { development in children aged } 5-6 \text { years with a correlation coefficient (r) } \\
0.628 \text {, there is a strong relationship between patterns foster parents with } \\
\text { fine motor development in children aged } 5-6 \text { years with a correlation } \\
\text { coefficient (r) = } 0.672 \text {. The results of this study are expected to be used as a } \\
\text { guide for parents who have not applied democratic parenting to their } \\
\text { children so that the child's motor development can grow optimally. }\end{array}$ \\
\hline
\end{tabular}

\section{PENDAHULUAN}

Anak pra sekolah merupakan anak dengan rentang usia 4 sampai dengan 6 tahun (Izzaty, 2017) Pada usia tersebut banyak hal dialami dalam perkembangan tumbuh kembang anak terutama fisik dan mental anak karena pada masa ini sering terjadi masalah perilaku sebagai akibat karena anak sedang dalam proses perkembangan kepribadian yang menuntut kebebasan. Salah satunya yang terkait perkembangan anak meliputi beberapa aspek antara lain aspek perkembangan motorik, kognitif, sosial - emosi, bahasa, moral, agama (Wiyani, 2014). Motorik kasar yaitu keterampilan yang melibatkan otot-otot besar seperti berlari, melompat memanjat dan keterampilan motorik halus sebagai hasil koordiansi otot-otot kecil dengan mata dan tangan seperti menggambar, menggunting, dan menempel kertas (Soetjiningsih, 2012).

Masalah yang terjadi pada anak usia dini terkait dengan keterampilan motorik

Corresponding author:

I Gusti Ayu Putu Satya Laksmi

ayuputusatya@yahoo.com

Media Keperawatan Indonesia, Vol 3 No 2, Juni 2020

e-ISSN: 2615-1669

ISSN: 2722-2802

DOI: https://doi.org/10.26714/mki.3.2.2020.54-62 
kasarnya yaitu ketidakmampuan mengatur keseimbangan, reaksi kurang cepat, dan koordinasi kurang baik. Sedangkan, masalah yang dialami pada bagian keterampilan motorik halusnya yaitu anak belum bisa menggambar bentuk yang bermakna dan anak sering belum bisa mewarnai apa yang digambar dengan rapi. Apabila masalah ini tidak tertangani, maka kesulitan masalah keseimbangan akan dibawa terus oleh anak bahkan saat anak belajar di SD anak akan mengalami kesulitan dalam membaca dan menulis (Wiyani, 2014).

Prevalensi anak yang mengalami gangguan perkembangan di seluruh dunia menurut data masih tinggi diantaranya ada di negara Amerika Serikat berkisar 12-16\%, di negara Thailand sebanyak 24\%, di negara Argentina sebanyak 22\% dan di negara Indonesia berkisar 13-18\%. Berdasarkan data dari Ikatan Dokter Anak Indonesia (IDAI) Provinsi Bali tahun 2013, telah melakukan pemeriksaan kepada 2.634 anak dari usia 0-72 bulan. Hasil pemeriksaan perkembangan sebanyak 53\% tidak normal, meragukan sebanyak 23\%, penyimpangan perkembangan sebanyak $30 \%$ diantaranya $10 \%$ anak yang mengalami penyimpangan perkembangan pada aspek motorik kasar dan 20\% anak yang mengalami penyimpangan pada aspek motorik halus (IDAI, 2013). Cakupan pelayanan anak balita menurut Dinkes Provinsi Bali (2017) tertinggi berada di kota Denpasar sebesar $178,96 \%$ sedangkan, di Kabupaten Badung sebesar 158,45\%. Puskesmas yang sudah mencapai target renstra yang ditetapkan sebesar $100 \%$ dan target nasionalnya $85 \%$ di Kabupaten Badung hanya 3 dari 13 puskesmas yaitu Puskesmas Abiansemal II (142\%), Puskesmas Mengwi II (113\%) dan Puskesmas Kuta Utara (116\%). Pada tahun 2017 cakupan pelayanan kesehatan anak balita di Kabupaten Badung yang terendah berada di Kuta 1 sebesar 56,5 \% dan Kuta Selatan sebesar 59,1\%. Jika di lihat dari tahun sebelumnya yaitu tahun 2016 cakupan pelayanan kesehatan anak balita lebih tinggi yaitu di Kuta 1 sebesar 92,7 \% dan Kuta Selatan sebesar 76,4\% (Dinkes Provinsi Bali, 2017).

Lingkungan yang mendukung sangat diperlukan anak agar anak mendapatkan stimulasi yang baik. Segala cara atau usaha dalam bentuk stimulasi sejak awal kepada anak dalam rentang usia 0 hingga 6 tahun sangat penting diberikan, dikarenakan anak-anak di umur tersebut diharapkan mengalami perkembangan otak yang berlangsung secara optimal dan hal tersebut sangat berpengaruh terhadap kehidupan anak-anak ke depannya (Wiyani, 2014). Upaya-upaya yang dapat dilakukan untuk mengatasi masalah perkembangan motorik kasar dan motorik halus pada anak balita yaitu memberikan stimulasi atau rangsangan secara dalam. Selain upaya diatas, hal yang dapat mempengaruhi perkembangan motorik kasar dan motorik halus pada anak adalah pola asuh orang tua.

Pola asuh orang tua adalah suatu bentuk pola interaksi/aktivitas yang dilakukan antara orang tua dan anak selama anak dalam proses pengasuhan. Yang termasuk ke dalam kegiatan pengasuhan ini tidak hanya berkaitan dengan bagaimana orang tua memperlakukan anak tetapi juga meliputi bagaimana cara orang tua mendidik anak, mendisiplinkan, membimbing, serta melindungi/menjaga anak dalam proses mencapai kedewasaan sesuai dengan aturan/nilai-nilai yang berlaku di masyarakat pada umumnya (Susanto,2011). Untuk mencapai tumbuh kembang yang optimal sesuai potensi yang dimiliki anak usia0-6tahun perlu dilakukan stimulasi dini dimana kegiatan ini untuk merangsang kemampuan dasar anak.

Kondisi orang tua/keluarga tidak memiliki pengetahuan yang cukup berkaitan dengan pola asuh yang bisa mempengaruhi tingkat kecerdasan emosi pada anak usia dini. Berdasarkan hasil penelitian didapatkan bahwa terdapat model pola asuh otoriter, perfeksionis, permisif. Dimana ditemukan situasi keluarga/orang tua yang tidak bisa 
menciptakan situasi yang hangat dan tidak bisa menunjukkan kasih sayang terhadap anak. Selain itu, terdapat orang tua yang bersikap tidak peduli sebagai orang tua. Ditemukan juga, orang tua yang belum menerapkan/memberikan contoh pola asuh yang tepat kepada anaknya. Penerapan pengembangan motorik kasar dan motorik halus pada anak usia 5-6 tahun di TK Kartini di Tuban sudah diterapkan, namun terkait pola asuh selama ini belum pernah dipantau/dievaluasi oleh pihak sekolah. Penelitian ini bertujuan untuk melihat peran orang tua dalam meningkatkan perkembangan motorik kasar dan motorik halus pada anak usia 5-6 tahun.

\section{METODE}

Penelitian ini menggunakan desain penelitian kuantitatif non-eksperimental jenis korelasional. Pendekatan yang digunakan adalah cross-sectional. Pengambilan sampel menggunakan tehnik non probability sampling jenis purposive sampling, dengan besar sampel 75 responden, yang dihitung dengan rumus Slovin Populasi dalam penelitian ini adalah semua siswa dan siswi di TK Kartini Tuban kelas B sebanyak 92 siswa dan di dapatkan 75 responden yang memenuhi kriteria inklusi orang tua yang bersedia menjadi responden dan kriteria eksklusi anak yang mengalami fraktur pada tangan/kakinya.

Penelitian dilakukan setelah mendapatkan surat ijin penelitian. Peneliti dibantu assisten/pembantu peneliti (mahasiswa semester akhir) memilih responden yang telah ditetapkan kemudian diberikan informed consent dan penjelasan prosedur penelitian.

Instrumen yang digunakan adalah kuesioner tentang pola asuh orang tua dan mengumpulkan data tentang perkembangan anak menggunakan instrumen lembar KPSP.
Memberikan kuisioner pola asuh orang tua kepada orang tua siswa, setelah orang tua selesai menjawab kuisioner, selanjutnya peneliti meminta ijin orang tua untuk dilakukan pemeriksaan KPSP ke anakanaknya. Peneliti dibantu enumerator melakukan pemeriksaan KPSP kepada responden. Pemeriksaan dilakukan selama 1 hari, dalam sehari 75 responden dapat diperiksa, 3 pemeriksa melakukan pemeriksaan kepada 75 responden, 1 responden diperiksa selama 10 menit. Pemeriksaan dibagi menjadi 2 kelas, kelas pagi sebanyak 32 responden dan kelas siang sebanyak 43 responden.

Data dianalisis secara univariat dan bivariate menggunakan SPSS. Penelitian ini menggunakan distribusi frekuensi yang disajikan dalam bentuk tabel baik pada karakteristik responden, variabel bebas yaitu pola asuh orang tua, dan variabel terikat yaitu perkembangan motorik kasar dan motorik halus pada anak usia prasekolah. Sedangkan uji bivariate menggunakan Spearman Rank.

\section{HASIL}

Penelitian ini dilakukan pada 75 responden. Hasil penelitian pada tabel 1 tentang distribusi frekuensi karakteristik subyek penelitian berdasarkan karakteristik orang tua, didapatkan hasil bahwa jenis kelamin responden laki-laki dan perempuan memiliki proporsi yang hamper sama, dengan usia rata-rata berada dalam kategori dewasa awal. Responden didominasi beragama hindu, dengan tingkat pendidikan didominasi pendidikan SMA dan bekerja sebagai karyawan. Pola Asuh Orang Tua didominasi oleh pola demokratis.

Hasil penelitian penelitian (tabel 2) menunjukkan bahwa jenis kelamin anak memiliki proporsi yang hamper sama antara laki-laki dan perempuan dengan usia 5-6 tahun. Hasil pengukuran motorik kasar anak menunjukkan bahwa sebagian besar anak memiliki motoric kasar yang sesuai 
dengan tahap tumbuh kembangnya. Hasil pengukuran motorik halus anak menunjukkan bahwa sebagian besar anak memiliki motorik halus yang sesuai dengan tahap tumbuh kembangnya.

Hasil analisis bivariat (tabel 3) diketahui bahwa terdapat hubungan yang signifikan antara pola asuh orang tua dengan perkembangan motorik kasar anak. Kekuatan hubungan kuat dengan arah hubungan yang searah. Sehingga dapat disimpulkan bahwa semakin baik pola asuh orang tua maka semakin baik pula perkembangan motorik kasar anak. Hasil analisis bivariat diketahui bahwa terdapat hubungan yang signifikan antara pola asuh orang tua dengan perkembangan motorik halus anak. Kekuatan hubungan kuat dengan arah hubungan yang searah. Sehingga dapat disimpulkan bahwa semakin baik pola asuh orang tua maka semakin baik pula perkembangan motorik halus anak.

Tabel 1

Karakteristik orang tua, $\mathrm{n}=75$ responden

\begin{tabular}{lcc}
\multicolumn{1}{c}{$\mathrm{n}=75$ responden } \\
\hline \multicolumn{1}{c}{ Indikator } & f & \% \\
\hline Jenis Kelamin & 36 & 48 \\
Laki-Laki & 39 & 52 \\
Perempuan & & \\
\hline Usia & 2 & 2.7 \\
Masa remaja akhir & 42 & 56 \\
Masa dewasa awal & 31 & 41.3 \\
Masa dewasa akhir & & \\
\hline Agama & 37 & 49.3 \\
Hindu & 35 & 46.7 \\
Islam & 3 & 4 \\
Kristen Protestan & & \\
\hline Pendidikan & 7 & 9.3 \\
SD & 11 & 14.7 \\
SMP & 47 & 62.7 \\
SMA & 10 & 13.3 \\
Perguruan Tinggi & & \\
\hline Pekerjaan & 26 & 34.6 \\
Karyawan & 23 & 30.7 \\
Wiraswasta & 9 & 12 \\
Wirausaha & 14 & 18.7 \\
IRT & 3 & 4 \\
Lainnya & & \\
\hline Pola Asuh Orang Tua & 69 & 92 \\
Demokratis & 4 & 5.3 \\
Otoriter & 2.7 \\
Permisif & & \\
\hline
\end{tabular}

Tabel 2

Karakteristik responden anak, $\mathrm{n}=75$ responden

\begin{tabular}{lcc}
\hline \multicolumn{1}{c}{ Indikator } & f & \% \\
\hline Jenis Kelamin & & \\
Laki-Laki & 36 & 48 \\
Perempuan & 39 & 52 \\
\hline Motorik Kasar & & \\
Sesuai & 65 & 86.6 \\
Meragukan & 8 & 10.7 \\
Penyimpangan & 2 & 2.7 \\
\hline Motorik Halus & $\mathbf{f}$ & $\mathbf{\%}$ \\
Sesuai & 72 & 96 \\
Meragukan & 3 & 4 \\
Penyimpangan & 0 & 0 \\
\hline
\end{tabular}

Tabel 3

Hubungan Pola Asuh Orang Tua Dengan Perkembangan Motorik Anak

\begin{tabular}{lcc}
\hline \multicolumn{1}{c}{ Indikator } & $\begin{array}{c}\text { Koefisien } \\
\text { korelasi }\end{array}$ & p \\
\hline $\begin{array}{l}\text { Hubungan pola asuh } \\
\text { dengan motorik kasar } \\
\text { anak }\end{array}$ & 0,628 & 0,0001 \\
\hline $\begin{array}{l}\text { Hubungan pola asuh } \\
\text { dengan motorik halus } \\
\text { anak }\end{array}$ & 0,672 & 0,0001 \\
\hline
\end{tabular}

Rank spearman test

\section{PEMBAHASAN}

Pola asuh orang tua adalah suatu bentuk interaksi/suatu bentuk pengasuhan yang ditunjukkan oleh orang tua kepada anaknya, dimana kegiatan ini meliputi orang tua memberikan dorongan ke anak dengan cara mengubah pengetahuan, perilaku, dan norma-norma yang dianggap sesuai diterapkan agar anak bisa belajar mandiri, tumbuh dan berkembang secara sehat, memiliki rasa percaya diri, memiliki rasa ingin tahu sekitar, bersahabat, dan berfokus untuk sukses (Tridonanto, 2014). Orang tua mereka merupakan pendidik bagi mereka pola asuh orangtua sikap serta situasi dan kondisi yang sedang melingkupi orang tua dapat mempengaruhi perkembangan anak (Wiyani, 2014).

Hasil ini sejalan dengan penelitian dari (Hastuti \& Dewi, 2016) sebagian besar mempunyai pola asuh yang efektif (Demokratis) sebanyak 29 responden 
(61,7\%). Penerapan pola asuh demokratis akan melatih anak untuk menjadi mandiri, dapat mengontrol/menahan diri, memiliki hubungan pertemanan yang baik, mampu mengatasi/mengontrol stres, memiliki ketertarikan dengan hal-hal yang baru dan bisa bekerjasama dengan orang lain.

Orang tua responden anak lebih banyak berada pada masa dewasa awal dalam rentang 26-35 tahun, yaitu sebanyak 42 orang (56\%). Usia orang tua sangat mempengaruhi pola asuh.

Orang tua yang tergolong ke dalam kriteria dewasa awal cenderung lebih mengikuti keinginan anak dibandingkan dengan orang tua yang berada di usia lebih tua. Komunikasi ke anak bisa dipengaruhi juga oleh usia. Dimana jarak usia yang terlalu jauh dengan anak, akan memerlukan kerja keras dalam memahami dunia anak. Sebagai catatan bahwa bagi orang tua harus paham dengan dunia anaknya ( Hurlock, 2011)

Penelitian ini sejalan dengan Windari, (2017) Berdasarkan dari 52 responden yang menikah dibawah 20 tahun memiliki balita usia prasekolah, frekuensi tertinggi pada pola asuh permisif sebanyak 29 responden (56\%) sedangkan frekuensi terendah pada pola asuh orang tua adalah penelantar sebanyak 2 responden (4\%), pola asuh demokratis sebanyak 7 responden $(13 \%)$ dan pola asuh otoriter sebanyak 14 reponden (27\%). Pola pengasuhan yang diterapkan dalam keluarga pada ibu yang menikah dibawah 20 tahun sebagian besar menggunkan pola asuh permisif. Sisi positif dari pola asuh permisif pada anak adalah semua perhatian bisa tertuju pada anak tapi sisi negatif dari jenis pola asuh ini jika anak sudah dewasa akan menyebabkan anak kurang bertanggung jawab, mempunyai kendali emosi yang buruk.

Selain pola asuh orang tua dan kualitas interaksi orang tua dan anak, faktor yang dapat mempengaruhi perkembangan anak, diantaranya adalah posisi anak dalam keluarga, jenis kelamin, jumlah saudara, pendidikan dan lingkungan. Kesulitan ibu dalam mendidik anak-anaknya dikarenakan tidak atau terbatasnya memiliki pengalaman, tidak memiliki pendidikan yang cukup tinggi dikarenakan ibu menikah di bawah usia 20 tahun. yang rendah juga bisa mempengaruhi perkembangan anak.

Sejalan dengan penelitian diatas menurut Imelda (2017), menjelaskan bahwa semakin dewasa usia orang tua akan lebih memahami dalam mengasuh, mendidik dan mencukupi kebutuhan gizi anak sehingga mampu meningkatkan perkembangan anak dibandingkan usia orang tua yang lebih muda.

Berdasarkan hasil penelitian didapatkan bahwa sebagian besar anak usia 5-6 tahun memiliki perkembangan motorik kasar yang sesuai yaitu sebanyak 65 orang $(86,6 \%)$. Perkembangan motorik kasar ada kaitannya dengan kemampuan gerak seorang anak yang berkembang sesuai dengan kematangan saraf dan otot anak. Perkembangan motorik kasar pada anak dipengaruhi oleh beberapa faktor, seperti faktor bakat (genetik), faktor lingkungan (gizi dan perawatan) serta perpaduan antara bakat dan lingkungan (Susanto, 2011). Kekuatan motorik memiliki keterkaitan dengan perkembangan neurologis, sehingga peningkatan keterampilan mencerminkan pertumbuhan fisik dan otak pada anak. Keterampilanketerampilan tersebut diperoleh dari faktor lingkungan serta pola asuh yang diberikan (Tri Sukma Ariyani \& Rinakit Adhe, 2018).

Andriani (2017) menjelaskan bahwa pola asuh demokratis cenderung menciptakan perkembangan motorik kasar jauh lebih normal. Sebaliknya anak yang mendapatkan pola asuh tidak demokratis cenderung mengalami perkembangan motorik kasar meragukan atau bahkan tidak normal. Pola asuh demokratis (authoritative/help) memberikan dampak yang lebih menguntungkan. Pola asuh demokratis adalah pola asuh yang mendorong anak 
untuk mandiri dengan memberikan kebebasan tetapi dengan sedikit kontrol (Santrock, 2011). Pola asuh ini membuat anak bebas untuk berkreatifitas untuk bergerak, sehingga ini akan sangat berpengaruh terhadap perkembangan yang cenderung lebih baik (Setyaningsih, 2012). Pola asuh otoriter akan menyebabkan anak mudah stress dan takut melakukan suatu tindakan (bermain, memanjang, melompat, dll), penakut dan merasa tidak bahagia sehingga tidak termotivasi untuk melakukan tindakan-tindakan yang seharusnya dilakukan oleh anak-anak seusianya (Andriani, 2017).

Hasil penelitian ini sejalan dengan penelitian (Andriani, 2017) yang menunjukkan bahwa dari 43 orang tua yang menerapkan pola asuh demokratis diketahui hampir setengahnya anak dengan perkembangan sesuai sebanyak 21 responden $(48,8 \%)$, dan hanya sebagian kecil anak dengan perkembangan meragukan sebanyak 17 anak (39,5\%) dan perkembangan menyimpang sebanyak 5 anak $(11,6 \%)$. Hasil penelitian tersebut menunjukkan bahwa anak dengan pola asuh demokratis dapat mempunyai perkembangan yang sesuai. Akan tetapi tidak tertutup kemungkinan anak juga dapat mengalami perkembangan meragukan dan menyimpang. Hal tersebut dikarenakan setiap pola asuh yang diberikan orang tua berbeda-beda, selain itu ada faktor lain yang dapat mempengaruhi perkembangan anak. Sedangkan, responden yang tipe pola asuhnya otoriter dari 5 orang tua sebagian besar anaknya mengalami perkembangan menyimpang sebanyak 3 anak (60\%) dan sebagian kecil dengan perkembangan meragukan sebanyak 2 anak (40\%). Hasil penelitian tersebut menjelaskan bahwa anak yang diasuh dengan pola asuh otoriter cenderung mempunyai anak dengan perkembangan meragukan dan menyimpang. Hal ini dapat dikarenakan kriteria atau ciri dari pola asuh otoriter yang cukup keras pada anak dan terlalu memproteksi anak dan memberikan hukuman jika melakukan kesalahan. Berdasarkan data hasil penelitian diketahui anak yang mengalami perkembangan meragukan dan menyimpang pada pola asuh otoriter ini dikarenakan anak sering dimarahi oleh orang tuanya jika melakukan kesalahan. Ketika saat melakukan observasi ada orang tua yang membentak anaknya ketika tidak bisa melakukan tahapan seperti berdiri dengan satu kaki. Selain itu anak merasa takut kalau melakukan sesuatu menjadi salah atau tidak sesuai keinginan orang tua, sehingga dalam hal ini anak terkadang dalam melakukan tahapan perkembangan ragu-ragu dalam melakukannya sehingga tidak bisa.

Berdasarkan penelitian didapatkan hasil bahwa sebagian besar anak usia 5-6 tahun sebagian besar anak memiliki perkembangan motorik halus yang sesuai yaitu sebanyak 72 orang (96\%). Motorik halus merupakan suatu bentuk gerakan halus yang melibatkan bagian tertentu dari otot kecil, dikarenakan gerakan ini tidak memerlukan tenaga (Susanto, 2011) Beberapa hal yang mempengaruhi perkembangan motorik halus anak adalah periode pranatal, faktor kesulitan dalam proses kelahiran, kesehatan, nutrisi, rangsangan, perlindungan, prematur dan adanya kelainan faktor genetik, faktor kesehatan (Rumini, 2013). Menurut Putiha (2015) mengatakan bahwa baik atau buruknya perkembangan motorik halus pada anak sangat erat kaitannya dengan pola asuh orang tua dalam mendidik dan mengasuh anaknya.

Hasil penelitian ini sejalan dengan penelitian yang dilakukan oleh Diana (2019) yang menunjukkan bahwa ibu yang menerapkan pola asuh dominan demokratif sebagian besar anaknya memiliki perkembangan motorik halus advance sebanyak 18 orang $(66,7 \%)$, sedangkan ibu yang menerapkan pola asuh dominan permisif seluruh anaknya memiliki perkembangan motorik halus peringatan (meragukan). 
Hasil penelitian tersebut sejalan dengan penelitian Sari (2015) didapatkan pola asuh orang tua demokratis dengan perkembangan motorik halus yang normal lebih besar 68,4\% (13 responden), pola asuh orang tua otoriter dengan perkembangan motorik halus lebih dari setengah responden yaitu 5 responden (55,6\%) mendapatkan hasil "peringatan" pada tes perkembangan motorik halusnya, pola asuh orang tua permisif dengan perkembangan motorik halus yang terlambat (T) sebanyak 2 responden (50\%). Orang tua yang menerapkan pola asuh demokratis menunjukkan bahwa perkembangan motorik halusnya lebih baik dibanding dengan pola asuh otoriter dan permisif. Apabila anak tidak mau melakukan apa yang diinginkan oleh orang tua maka anak akan dihukum, anak cenderung dipaksa, dan diperintah oleh orangtuanya, merupakan penerapan dari pola asuh otoriter. Sehingga, akan membuat anak tidak percaya diri, merasa takut apabila berbuat kesalahan, dan susah percaya kepada sekitarnya. Sedangkan penerapan pola asuh permisif adalah orangtua memberikan pengawasan yang sangat longgar kepada anaknya, dan memberikan kebebasan ke anak untuk melakukan apapun tanpa diawasi oleh orangtuanya. Orang tua yang menerapkan pola asuh permisif dominan tidak menegur atau mengingatkan ke anak apabila melakukan kesalahan, selain itu berdampak membuat anak menjadi manja, kurang mandiri, tidak patuh, mau menang sendiri.

Hasil analisis bivariat hubungan pola asuh orang tua dengan perkembangan motorik kasar pada anak usia 5-6 tahun menunjukkan nilai $\mathrm{p}$-value $=0,000$ atau $\mathrm{p} \leq$ 0,05 dengan nilai koefisien korelasi ( $\mathrm{r}$ ) $=0,628$. Hasil ini mengindikasikan bahwa Ho penelitian ditolak yang berarti ada hubungan yang kuat antara pola asuh orang tua dengan perkembangan motorik kasar pada anak usia 5-6 tahun.

Pola asuh orang tua yaitu bentuk interaksi orang tua dengan anak, dimana orang tua memberikan dukungan ke anak dengan mengubah perilaku, pengetahuan agar anak bisa menjadi mandiri, tumbuh serta berkembang secara sehat, memiliki rasa percaya diri, memiliki rasa ingin tahu, mampu berinteraksi dengan sekitar (Tridonanto, 2014). Setiap orang tua memiliki cara tersendiri dalam mengasuh anaknya, yang akhirnya akan mempengaruhi anak dalam hal perkembangannya (Wong, 2009).

Sejalan dengan teori diatas, Andriani (2017) mengungkapkan bahwa adanya kesempatan yang diberikan orang tua pada anak, maka anak akan berupaya maksimal untuk melakukan suatu perkembangan baru dalam motoriknya, dengan adanya kesempatan untuk memilih melakukan suatu tindakan maka anak bisa memutuskan dan melakukan tindakan sesuai dengan keinginan dan kemampuannya seperti memanjat, melompat-lompat, dll. Hal ini akan mempengaruhi kemampuan anak dan berdampak pada perkembangan motorik kasarnya. Perkembangan anak yang terlambat dapat terjadi ketika orang tua juga tidak memberikan stimulasi sesuai dengan usia anak serta memberikan lebih sering ganjaran atau hukuman yang berlebihan ketika anak melakukan kesalahan, atau ketika anak tidak mampu serta saat orang tua yang cenderung melarang melakukan sesuatu yang diperintahkan.

Hasil penelitian ini sejalan dengan penelitian Fitriati (2014) dalam penelitiannya yang menyatakan ada hubungan antara pola asuh ibu dengan perkembangan motorik kasar pada anak pra sekolah usia 4-5 tahun di RA Ibrohmiyyah, dengan nilai $p=0,007$. Penelitian ini juga sejalan dengan penelitian yang dilakukan oleh Neny (2017) yang menyatakan bahwa ada hubungan antara pola asuh orang tua dengan perkembangan motorik kasar pada anak usia prasekolah di Tempat Penitipan Anak (TPA) Baituttaqwa Kecamatan Takeran dengan nilai p- 
value $=0,00$.

Hasil analisis bivariat hubungan pola asuh orang tua dengan perkembangan motorik halus pada anak usia 5-6 tahun menunjukkan nilai $\mathrm{p}$-value $=0,000$ atau $\mathrm{p} \leq$ 0,05 dengan nilai koefisien korelasi ( $\mathrm{r}$ ) $=0,672$. Hasil ini mengindikasikan bahwa Ho penelitian ditolak yang berarti ada hubungan yang kuat antara pola asuh orang tua dengan perkembangan motorik halus pada anak usia 5-6 tahun.

Pola asuh merupakan gabungan dari penerimaan, respon, aturan serta tuntutan yang diberikan oleh orang tua kepada anak (Santrock, 2011). Pola asuh yang diterapkan orang tua pada anaknya memberikan pengaruh cukup besar dalam kehidupan anak di masa mendatang. Penerapan pola asuh bisa dilakukan orang tua dengan cara memberikan perhatian tulus kepada anak dan orang tua menyediakan waktu yang cukup ke anakanaknya agar bisa selalu bersama (Desmita, 2015). Cara orang tua dalam pengasuhan berinteraksi dengan anak mempengaruhi interaksi anak di luar rumah (Riyadi, 2009).

Sejalan dengan teori diatas, Sari (2015) menjelaskan bahwa perkembangan motorik halus pada anak tergantung dari stimulasi dan pola asuh orang tua. Bagi anak yang diberikan stimulasi/bimbingan yang baik akan lebih cepat berkembang dibandingkan dengan anak yang terbatas/tidak mendapat stimulasi. Anak dengan keadaan yang normal, meskipun keterampilan motorik halus dapat berkembang dengan sendirinya, namun stimulasi tetap diberikan untuk lebih mengasah ketrampilan tersebut sehingga dapat berkembang dengan lebih baik lagi.

Peran pola asuh sangatlah penting dalam pembentukan kepribadian anak, seperti untuk perkembangan motorik halus anak. Penerapan pola asuh orang tua dikaitkan dengan kemampuan orang tua memahami karakteristik anak sehingga dalam berinteraksi, anak merasa nyaman. Orang tua yang memberikan kasih sayang dan perhatian kepada anaknya akan membuat anak menjadi berani berinteraksi dengan sekitar, kreatif, anak merasa tidak takut untuk mencoba hal baru sehingga perkembangan anak akan optimal (Fatimah, 2012).

Temuan pada penelitian ini sejalan dengan penelitian yang dilakukan oleh Frenanda (2011) yang menyatakan bahwa ada hubungan signifikan antara hubungan pola asuh ibu dengan tingkat perkembangan motorik halus pada anak di TK ABA Kendangan, Caturharjo, Sleman dengan nilai $\mathrm{p}=0.004$. Penelitian lainnya juga menunjukkan bahwa ada hubungan antara pola asuh orang tua dengan perkembangan motorik halus anak usia 5-6 tahun di TK Aisyiyah Banjarmasin dengan $\mathrm{p}$ value $=$ 0,013 (Redjeki \& Anggarani, 2015).

\section{SIMPULAN}

Terdapat hubungan yang signifikan antara pola asuh orang tua dengan perkembangan motorik kasar anak. Semakin baik pola asuh orang tua maka semakin baik pula perkembangan motorik kasar anak. Terdapat hubungan yang signifikan antara pola asuh orang tua dengan perkembangan motorik halus anak. Semakin baik pola asuh orang tua maka semakin baik pula perkembangan motorik halus anak. Sehingga peran orang tua diperlukan untuk meningkatkan perkembangan motoric kasar dan motoric halus pada anak usia 5-6 tahun.

\section{UCAPAN TERIMAKASIH}

Penghargaan setinggi-tingginya untuk $\mathrm{Ni}$ Kadek Sinta Purnama Febriasari, responden penelitian dan assisten/pembantu peneliti dalam penelitian ini.

\section{REFERENSI}

Andriani, M. (2017). Hubungan Pola Asuh Orang Tua Terhadap Perkembangan Motorik Kasar Pada Balita Usia 3-5 Tahun di Wilayah Kerja Puskesmas Simpati Kecamatan Simpati 
Kabupaten Pasaman Tahun 2015. 'AFIYAH, $3(1)$.

Desmita. (2015). Psikologi Perkembangan. Bandung: Pt. Remaja Rosdakarya.

Diana, W. (2019). Hubungan Pola Asuh Orang Tua Dengan Perkembangan Motorik Halus Anak Usia Prasekolah (Di PAUD Harapan Bunda Surabaya). J-HESTECH (Journal of Health Educational Science And Technology), 2(1), 5160.

Dinkes Provinsi Bali. (2017). Profil Kesehatan Provinsi Bali.

Fatimah, L. (2012). Hubungan Pola Asuh Orang Tua dengan Perkembangan Anak di RA Darussalam Desa Sumber Mulyo, Jogoroto, Jombang. Prosiding Seminas, 1(2).

Fitriati, U. (2014). Hubungan Pola Asuh Orang Tua Dengan Perkembangan Motorik Kasar Pada Anak Pra Sekolah Usia 4-5 Tahun Di RA Ibrohimiyyah Mranggen Kecamatan Mranggen Demak. Fakultas Kedokteran UNISSULA.

Frenanda, E. L. (2011). Hubungan Pola Asuh Ibu dengan Tingkat Perkembangan Motorik Halus pada Anak Di TK ABA Kendangan Caturharjo Sleman. STIKES’Aisyiyah Yogyakarta.

Hastuti, W., \& Dewi, S. N. S. K. (2016). Hubungan Pola Asuh Orang Tua dan Pemberian Stimulus Alat Permainan Edukatif (APE) Terhadap Perkembangan Motorik Halus Anak di PAUD Kelurahan Sendangguwo. Jurnal Smart Keperawatan, 3(2), 59-68.

Hurlock, E. (2011). Psikologi Perkembangan. Jakarta: Erlangga.

IDAI. (2013). Mengenal Keterlambatan Perkembangan Umum Pada Anak.

Imelda, I. (2017). Pengetahuan Ibu Tentang Pemberian Stimulasi Dan Perkembangan Anak Pra Sekolah (3-5 tahun) di Banda Aceh. Idea Nursing Journal, 8(3).

Izzaty, R. E. (2017). Perilaku Anak Pra Sekolah. Jakarta: PT. Elex Media Komputindo.

Neny, W. Y. (2017). Hubungan Pola Asuh Orang Tua Dengan Perkembangan Motorik Kasar Pada Anak Usia Prasekolah Di Tempat Penitipan Anak (TPA) Baituttaqwa Kecamatan Takeran. STIKES Bhakti Husada Mulia.

Putiha, S. (2015). Hubungan Pola Asuh Orang Tua
Terhadap Perkembangan Motorik Halus Anak pada Usia 3-5 Tahun di KB Cahaya Ilmu. SELING: Jurnal Program Studi PGRA, 1(1), 7483.

Redjeki, D. S. S., \& Anggarani, R. P. (2015). Hubungan Pola Asuh Orang Tua Dengan Perkembangan Motorik Halus Anak Usia 5-6 Tahun Di TK Aisyiyah Banjarmasin. Dinamika Kesehatan Jurnal Kebidanan Dan Keperawatan, 6(1), 104112.

Riyadi, S. \& S. (2009). Asuhan Keperawatan Pada Anak. Yogyakarta : Graha Ilmu.

Rumini, S. (2013). Perkembangan Anak Dan Remaja. Jakarta: Rineka Cipta.

Santrock, J. W. (2011). Perkembangan Anak. Jakarta : Salemba Harmonika.

Sari, R. O. (2015). Hubungan Pola Asuh Orang Tua Dengan Perkembangan Motorik Halus Anak Usia 4-6 Tahun Di Tk Dharma Wanita Suruhan Lor Kecamatan Bandung Kabupaten Tulungagung. Jurnal Ilmu Keperawatan Dan Kebidanan, 7(3).

Setyaningsih, A. (2012). Hubungan Pola Asuh Orang Tua Dengan Perkembangan Motorik Kasar Anak Usia 1-3 Tahun. Jurnal Kebidanan, 4(2).

Soetjiningsih, C. H. (2012). Perkembangan Anak. Jakarta: Prenada.

Susanto, A. (2011). Perkembangan Anak Usia Dini. Jakarta: Kencana.

Tri Sukma Ariyani, S., \& Rinakit Adhe, K. (2018). Survei Pola Asuh Orang Tua Dengan Perkembangan Gerak Lokomotor Anak TK A Di Surabaya Pusat. PAUD Teratai, 7(2).

Tridonanto, A. (2014). Mengembangkan Pola Asuh Demokratis. Retrieved from https://books.google.co.id/books?id=JuBMDw AAQBAJ

Windari, E. N., Trisintyandika, I., \& Santoso, D. (2017). Hubungan Pola Asuh Orang Tua Dengan Perkembangan Anak Prasekolah Pada Ibu Yang Menikah Dini Di Wilayah Puskesmas Jabung. Journal of Issues in Midwifery, 1(1), 4146.

Wiyani, N. A. (2014). Psikologi Perkembangan Anak Usia Dini. Yogyakarta: Gava Media.

Wong, et al. (2009). Buku Ajar Keperawatan Pediatrik. Jakarta. EGC. 